\title{
René Cassin and the Daughter of Time: The First Draft of the Universal Declaration of Human Rights
}

\author{
by A.J. Hobbins
}

In the forty years since the U. N. General Assembly adopted the Universal Declaration of Human Rights, no definitive history of the drafting process has been written. The events of the two years leading up to the adoption are dealt with in cursory and often conflicting fashion in most general studies of the Declaration. The McGill University Law Library houses the handwritten manuscript of the original draft of the Declaration, which is published bere for the first time. The facts surrounding its production, evolution and early use are cbronicled, based on primary $U . N$. documents as well as the memoirs of some of the principals in the process, including Eleanor Roosevelt, first Chairman of the Commission on Human Rights; René Cassin, Nobel Laureate and French Representative on the Commission; and John Humphrey, a Canadian lawyer who was Director of the Human Rights Division of the U.N. Secretariat.

Quarante ans se sont écoulés depuis l'adoption de la Déclaration universelle des droits de l'bomme par l'Assemblée générale des Nations unies. Cependant, aucune bistoire définitive du processus d'élaboration de la Déclaration n'a encore été écrite. Les événements qui ont marqué les deux années précédant son adoption sont relatés de manière superficielle et contradictoire dans la plupart des études consacrées à ce sujet. La bibliothèque de droit de l'université McGill possède un manuscrit de la version originale de la Déclaration, lequel est publié dans ces pages pour la première fois. Le processus de la rédaction, de l'évolution et de l'application de la Déclaration font ici l'objet d'une chronique, fondée sur les archives des Nations unies et les mémoires de ses trois principaux instigateurs: Eleanor Roosevelt, premier président de la Commission des droits de l'homme; René Cassin, prix Nobel de la paix et délégué français auprès de la Commission; et John Humphrey, juriste canadien et ancien directeur de la division des droits de l'bomme au Secrétariat des Nations unies.

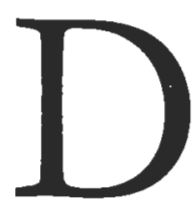

ecember 10,1988 , marked a number of anniversaries: the death of Alfred Nobel (1896), the adoption of the Universal Declaration of Human Rights by the United Nations (1948) and the awarding of the Nobel Peace Prize to René Cassin (1968). The inextricable link between these events was the fact that Cassin was awarded the prize for his work in getting the Universal Declaration adopted and that since that time he had "tirelessly worked for the carrying out of its rules both universally and on the European level." Indeed, Cassin's career prior to being awarded the prize was long and distinguished. He had been a French delegate to League of Nations Assemblies and Disarmament
Conferences from 1924-38 and, after the war, a member of the U. N. Commission on Human Rights, its Drafting Committee (1947-48) and later its Vice-Chairman (1949) and Chairman (1955). He had also been a judge of the European Court of Human Rights from 1959 and its President from 1965.

Cassin is widely reputed to be the author of the Universal Declaration, although he never made this claim. In fact such a suggestion could be considered specious in that many people and governments were involved over a significant period of time honing a variety of drafts. Nonetheless Cassin was one of the leading lights in the Commission which laboured long, hard 


\section{René Cassin and the Daughter of Time}

and successfully to produce an acceptable document. He does claim, however, to be the sole author of the first draft upon which subsequent work was based. ${ }^{2}$ This claim is echoed in many reputable sources.

Cassin's remembrance of how the first draft of the Universal Declaration was written is readily available. He states that the eight-man drafting committee called on him to prepare a preliminary draft Declaration on "the basis of material assembled by Professors John P. Humphrey and Emile Giraud," and proposals submitted by Panama and Cuba. ${ }^{3}$ Elsewhere Cassin described the "material assembled" in more specific terms as "un excellent travail documentaire de base élaboré au secrétariat des Nations-Unies [sic] par les Professeurs Humphrey et Giraud..." 4 However, he states this documentation could not stand the course of oral debate and he continued, "C'est pourquoi je fus chargé par mes collègues de rédiger, sous ma scule responsabilité, un premier avantprojet."'5 The draft consisted of a preamble and 45 articles which he submitted to the Committee on June 3, 1947. Thus it was, he recalls, that at the request of his colleagues he became solely responsible for writing the first draft.

While these memories have generally been accepted as fact, they have been contradicted consistently, if quietly at first, for some time. Professor John P. Humphrey, ${ }^{6}$ a lawyer and scholar of great eminence in the field of human rights, has a different recollection. Humphrey, as Director of the Human Rights Division of the U.N. Secretariat, was present at most meetings of the Commission and its various committees, frequently as Secretary. By virtue of his position he was uniquely qualified to recall events and for him the story began earlier.

The Commission on Human Rights met for its first regular session under the chairmanship of Eleanor Roosevelt on January $27,1947 . .^{7}$ (Figure 1) One of the most important orders of business was to make arrangements for the drafting of an international bill of human rights. The Commission was split on how to proceed. The representatives of Australia and the United Kingdom had recommended that the Secretariat be expressly responsible for the production of a draft under the general supervision of the Commission's Officers, that is the Chairman, the Vice-Chairman, P. C. Chang of China, and the
Rapporteur, Charles Malik of Lebanon (Figure 2). The majority felt, however, that the Commission would be abrogating its authority if it proceeded in this way. Eventually Malik found the wording for a resolution which allowed the Secretariat to do the work while the Commission retained its responsibility. The resolution read in part as follows:
That the Chairman of the Commission on Human Rights, together with the Vice-Chairman and Rapporteur, undertake with the assistance of the Secretariat, the task of formulating a preliminary draft international bill of human rights...

This resolution establishing the Drafting Group was adopted on February third. ${ }^{8}$

Cassin was later to state that he was opposed to the establishment of the Drafting Group. He wrote:

Mais elle [Mme. Roosevelt] a pris, contre l'avis des représentants soviétique et français, une décision de procédure qui ne peut s'expliquer que par la volonté d'être prête pour l'Assemblée de 1947: celle de confier à son bureau comprenant la prêsidente, le vice-présidente et le rapporteur, le soin d'élaborer, avec le concours du secrétariat, un premier avant-projet de déclaration, sous forme de résolution de l'Assemblée."

The fact that the Drafting Group subsequently proved to be unworkable would indicate that those who opposed it were prudent and had foresight. However, Cassin's claimed opposition is not sustained by an examination of the summary records of the meetings, which state:

Mr. Cassin (France) pointed out that it was manifestly impossible for the Commission itself to do the drafting work; neither could the Secretariat do that work, since that would imply a derogation of the Commission's mandate. He favoured, therefore, the Rapporteur's proposal, since the Commission could carry out its duties through its Chairman. In view of the fact that Mrs. Roosevelt would not be available during some of the time between sessions, two or four other 

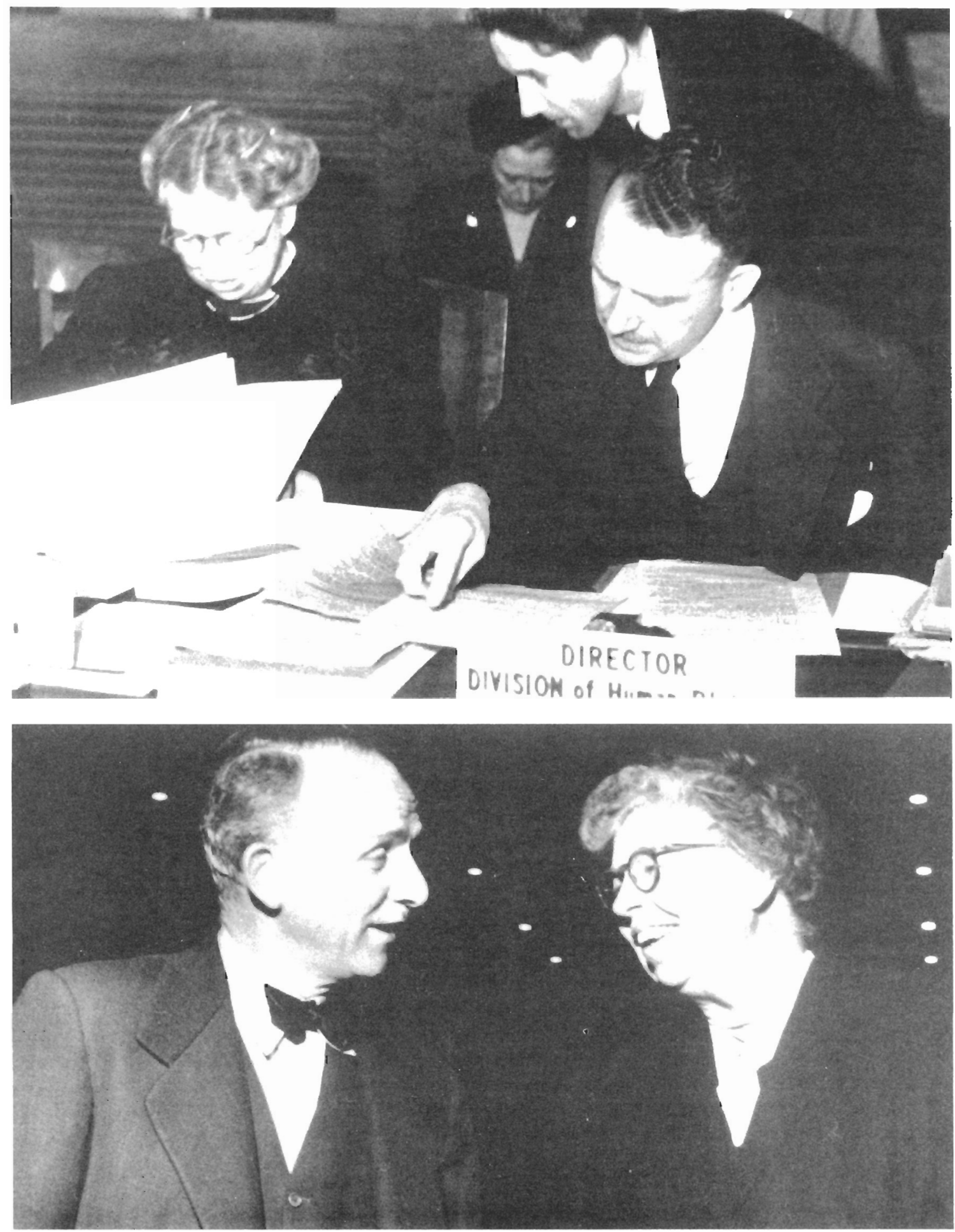

Figure 1. John Humphrey and Eleanor Roosevelt. (See note 44). 
members of the Commission should be designated to assist her, and to form a small Committee. ${ }^{10}$

In the lunch break between the eleventh and twelfth meetings, Cassin, Malik and Ribnikar, the Yugoslavian representative, worked on the draft resolution which after some slight amendment in the twelfth meeting established the group. The resolution was adopted without dissent. "1 Tepliakov, the Russian representative, later withdrew support for the arrangement after consulting his government. It seems probable, therefore, that Cassin's memory of opposition to a measure he had in fact advocated reflected the unerring accuracy of hindsight rather than foresight.

The Drafting Group did not meet often. Malik, in his address to the General Assembly, said:

\begin{abstract}
This small group convened several times informally at Mrs. Roosevelt's home, but met with great difficulty in performing the tremendous task assigned to them for it was hardly possible for them to be aware of all the trends of thought on human rights and fundamental freedoms which existed in the world. ${ }^{12}$
\end{abstract}

Humphrey and Roosevelt each recalled the group meeting only once during which the deep philosophical divisions between Malik and Chang became apparent. Malik, a devout Christian, believed the question of rights should be approached through Christian precepts, especially the teachings of St. Thomas Acquinas. Chang argued for a broader approach and suggested, tongue in cheek, that Humphrey, before he prepared the first draft, go to China for six months to study Confuscianism. Roosevelt, who on her own admission found herself somewhat out of her depth in these difficult discussions, remained silent and poured tea. ${ }^{13}$ Malik evidently took Chang's point for, in his Plenary Session speech when he stated those involved were too numerous to mention individually, he made an exception for Chang whom he thanked as follows:

But I must refer to Dr. P.C. Chang, this distinguished Vice-Chairman of the Commission and drafting committee, who has never failed to broaden our perspective by his frequent references to the wisdom and philosophy of the Orient and who, by a special drafting gift, was able happily to rectify many of our ternis. ${ }^{14}$

The only action taken by the Drafting Group was to ask Humphrey to prepare a draft international bill of rights.

Humphrey worked on a draft for the next six weeks, producing a manuscript, five typed drafts and, finally, a mimeograph dated March 15. Meanwhile the Commission on Human Rights was debating the wisdom of dividing the international bill into two parts: a Declaration, which would not be binding on individual states, and a Convention, which would be. The Soviet Union was also becoming more vociferous in its ojections to the drafting process. On March 24 Roosevelt, wisely though possibly illegally, wrote to the President of the Economic and Social Council informing him that she had established a new eight member drafting committee, which included representatives from the Soviet Union and France. ${ }^{15}$ Cassin, in this connection later wrote that the two problems of the original committee were firstly that there was no European representation - "Omission symbolique" - and secondly that, despite the fact that French was an official U. N. language, everything appeared to originate in English and the retranslations into French did not conform with his initial texts. ${ }^{16}$ The Economic and Social Council accepted Roosevelt's suggestion for a new committee and at the same time requested the Secretariat to provide the members with an outline at their next meeting. ${ }^{17}$

The Economic and Social Council's request for an "outline" created a number of difficulties in the interpretation of subsequent events. Humphrey chose to interpret an outline freely and, having already completed a draft international bill, he retitled the same text Draft Outline of International Bill of Rights. As Secretary of the new drafting committee, Humphrey submitted this text, which became known as the Secretariat Outline, at the first meeting on June 9. He also submitted a massive compilation, prepared by the Secretariat staff, entitled Documented Outline. This was 408 pages of supporting documentation arranged as a commentary on the Secretariat Outline, article by article. ${ }^{18}$ These two documents appear to 

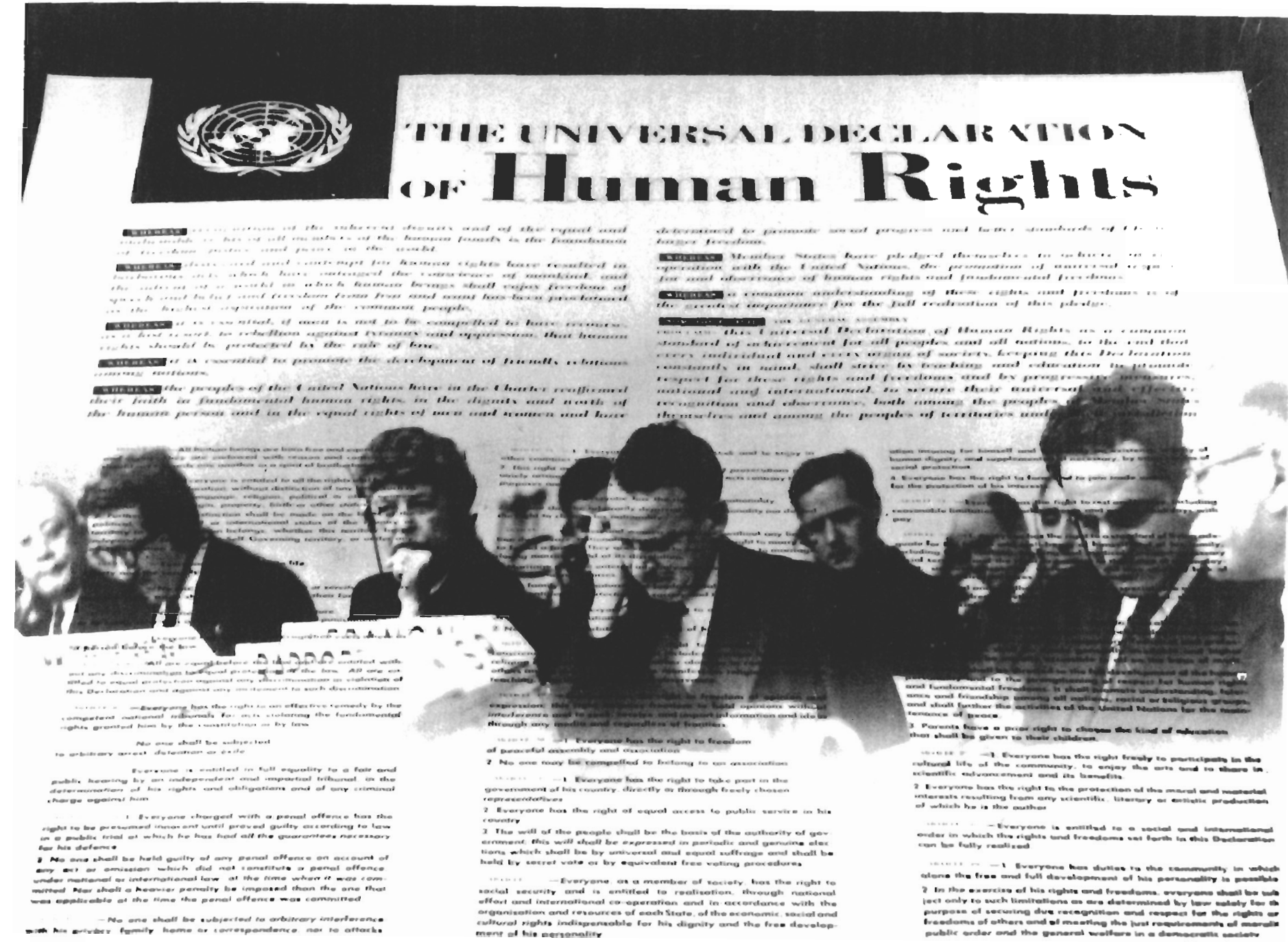

Figure 2. U.N. poster publicizing the Declaration, circa 1949. (See note 45). 
have been confused. Cassin must have been talking of the latter when he stated the work of the Secretariat could not stand the course of oral debate, forgetting he was also given the former. Malik described the work done by the Secretariat as follows:

It was, therefore, the international Secretariat of the United Nations, in particular Dr. John Humphrey of the Division of Human Rights, who prepared the first draft documented outline of an International Bill of Human Rights. This was a tremendous work of documentation covering over 400 pages. It is a matter for independent research to trace back our present fully developed articles to the rudiments in that basic compilation. The present declaration may therefore be said to have been constructed upon a firm international basis wherein no regional philosophy or way of life was permitted to prevail. For the Secretariat draft outline was a synthesis not only of all the hundreds of suggestions that had been made by governments, by private organizations, and by individuals, but also of law and practise in all the various Members of the United Nations. ${ }^{19}$

The Drafting Committee established a temporary Working Group, consisting of Roosevelt (ex officio), Malik, Cassin and the United Kingdom representative, Geoffrey Wilson, to advise it on how to proceed. On June 13 the Working Group, feeling any document would have greater unity if drawn up by an individual, requested Cassin to "undertake the writing of a draft Declaration based on those Articles in the Secretariat Outline which he considered should go into such a Declaration. "20 The other members considered the matters of a convention and implementation. Cassin completed his task over a single weekend with the assistance of Emile Giraud of the Secretariat. ${ }^{21}$ This time frame would certainly indicate that his draft was based on research already undertaken. Thus while Cassin had some of the leeway implicit in his remembrance, there were also clearly restrictions in terms of the Secretariat Outline. Although Cassin states in several places his "avant-projet" was submitted on June 3 , this was clearly impossible. ${ }^{22}$ It was actually handed in on Monday, June $16^{23}$

Humphrey maintains that the Cassin draft reproduced the Secretariat Outline in most of its essentials. He describes the changes as follows:

Some of his articles were no more than a new French version of the official United Nations translation of the English original. He also changed the order of some of the articles, combined in one article principles the Secretariat draft had expressed in two and divided some of them into two or more articles; and he left out some of the articles because in his opinion, they could be more appropriately included in a convention. Many of his changes and in particular the changed order did not survive the test of time. ${ }^{24}$

It can certainly be shown that Humphrey was the author of the Secretariat Outline. The manuscript and annotations on the typed drafts are all in Humphrey's handwriting, although he acknowledged receiving some help from Giraud in terms of reading and commenting on his work. ${ }^{25}$ It is equally evident that the Outline predated Cassin's draft and that Cassin had access to it while preparing his. If, as Humphrey suggests, the Cassin draft was derivative in nature and clearly based on the Outline, then Humphrey not Cassin should be given credit for the first draft. It should be noted, of course, that if Cassin's draft was derivative, he was only doing precisely what he was asked to do. In December 1948, Malik compared the two drafts in the following terms: "If the Secretariat draft was the primordial womb of our declaration, the Cassin text was the first-born of that womb." 26

It would require an independent scholar of impeccable credentials to evaluate the accuracy of Humphrey's assertion and the extent to which Cassin's work was derivative. However, even the untutored eye can detect significant resemblances between the official French translation of the Secretariat Outline (SO) and the Cassin Draft (CD), a few examples of which are presented here. 


\section{SO Article 2}

Les droits de chacun sont limités par ceux d'autrui et par les justes exigences de l'Etat et des Nations Unies.

\section{SO Article 13}

Tout individu a le droit de contracter mariage conformément aux lois.

\section{SO Articles 43 and 44}

Tout individu a droit à une juste part de repos et de loisir.

Tout individu a le droit de prendre part à la vie culturelle de la société, de jouir des arts et departiciper aux avantages de la science.

\section{Article 4}

Les droits de chacun sont limités par ceux d'autrui.

\section{Article 17}

Tout individu a le droit de contracter mariage en se conformant aux lois.

\section{Article 42}

Tout individu a droit à une juste part de repos et de loisir et de connaissance du monde extérieur.

Tout individu a le droit de prendre part à la vie culturelle de la société, de jouir des arts, de participer aux bienfaits de la science.
There are many other similarities and it would appear that the question indeed warrants further study.

There were also several significant differences between the two texts. The Preambles are dissimilar and the concept from Cassin's Article I "Les ètres humains... doivent se regarder comme des frères" is not evident in the Secretariat Outline. Cassin indeed stressed his belief that the concept of brotherhood had a higher value than individual rights. He wrote that:

\section{However, as soon as the Drafting Committee... met in June 1947, it commended its Rapporteur, who, following the principles of the French Revolution of 1789 and in strong reaction to Hitler's totalitarian oppression, had not begun by enumerating individual freedoms, nor even by stating the most fundamental rights, as the right to life, but had placed first a categorical affirmation of a higher value which makes life itself worthwhile. ${ }^{27}$}

In clearly referring to himself, it is something of a mystery why Cassin should consider he was the Rapporteur. His biographer and a President of France, amongst others, have also stated he held this office, but he was never Rapporteur of cither the Commission or the Drafting Committee. ${ }^{28}$
Humphrey, like Cassin in another context, questioned the quality of the official U.N. translations of texts. He felt that the process made the English translation of the Cassin draft more dissimilar from the original Secretariat Outline than it actually was. He wrote that Cassin:
... merely prepared a new French version of the official United Nations translation of the original English, and when this was translated back into English the result seemed further removed from the original than it really was. ${ }^{29}$

It is not hard to find examples of this type of problem. The Secretariat Outline, Article 48 , uses the phrase "National Law", which in the French translation becomes "droit national". The Cassin draft, Article 45, uses this precise language but the English translation specifies "Municipal Law". Any evaluation of the texts should, therefore, use the official French translation of the Secretariat Outline and the original of the Cassin draft.

Scholars will have to make textual comparisons to resolve questions such as outline versus draft and who may be responsible for which text. Cassin's original handwritten draft, displayed at the request of the French government in the United Nations Headquarters 
on the loth anniversary of the Universal Declaration, is partly reproduced in his book, $L a$ pensée et l'action. ${ }^{30}$ The typed text of Cassin's draft (from which this author worked) appears as Annex $\mathrm{D}$ of the UN Document $\mathrm{E} / \mathrm{CN} .4 / 21$, along with Annex $A$, the official French translation of the Secretariat Outline. The Law Library at McGill University houses the original Humphrey manuscript and subsequent drafts which resulted in the Secretariat Outline. ${ }^{31}$ As a further step to providing scholars with the necessary pieces of the puzzle, the original manuscript is described and transcribed here for the first time, including comparisons with the first typed draft.

\section{The Secretariat Outline}

As was noted earlier, the original Drafting Group had asked Humphrey to prepare a draft early in February. Humphrey studied a number of texts on the subject prepared by individuals and organizations. These included, amongst others, work by Gustavo Gutierrez, H. G. Wells, and Hersch Lauterpacht, as well as material from the American Law Institute, the American Jewish Congress, and the World Government Association. ${ }^{32} \mathrm{He}$ then prepared a manuscript which, along with the first typed draft, was undated. There followed the second typed draft (February 27), the third typed draft (February 28), the fourth typed draft (March 5) and the fifth typed draft (March 6). These dates were added in ink at the top of each first page in Humphrey's hand but it is uncertain when. The date for the third typed draft indicates it was shown to Mrs. Roosevelt at that time. ${ }^{33}$ The mimeograph of the fifth typed draft bears as part of the text the date of March 15.

\section{The Manuscript Draft}

The manuscript draft, in Humphrey's own hand, provides a fascinating insight into the creation of the final document. It shows where the ideas flowed freely, where there were problems, where there were second or third thoughts, and where avenues were abandoned. It is clear that several sheets are missing since one sentence begins in the middle and, indeed, Articles VIII and IX do not appear at all. The first part of the manuscript is written in pencil, while the remainder is in ink.

Sheets 1 to 3 are on $81 / 2$ " $\times 11$ " white lined paper. Sheet 4 is on the verso of 3 . Sheets 5 to 17 are written on 6" $\times 9$ ' ' buff unlined paper. ${ }^{34}$ Sheet 6 is on the verso of 5 and Sheet 17 on the verso of 16 . Sheets $18-23$, again on $81 / 2$ " $x 11$ "' white lined paper, are written in ink and certainly date from a later period, i.e. probably a matter of several weeks when the third typed draft was prepared. Sheets 19-23 are not reproduced in this article since they are unconnected with the first draft. All the sheets arc brittle, indicating high acid content in the paper, but no text has been lost through this decay. Humphrey's method of erasure was to strike a line through the offending word, or occasionally to use a scribble if a paragraph was involved. The discarded text is quite legible and is reproduced here in italic print. Only one erased word could not be identified. Editorial notes appear in square brackets and sheet numbers have been added for each page. The manuscript draft is then as follows:

\section{Sheet 1}

The preamble shall enunciate the following principles:

1. that there must be respect for human if [sic] rights and freedoms if the world is to know peace;

2. that man does not have rights only: he owes duties to the society (both national and international) of which he forms part.

1. The provisions of this International Bill of Rights shall be deemed fundamental principles of international law and of the national law of each of the member States of the United Nations. Its observance is therefore a matter of international concern and it shall be within the jurisdiction of the United Nations to discuss any violation thereof.

[Article I first typed draft]

1a 1t is the duty of the State to respect and maintain the rights enunciated in the Bill of Rights.

[Section la was added later and became the basis for Article 11 in the first typed draft] 


\section{René Cassin and the Daughter of Time}

1b Every one owes a duty of loyalty to his State and to the international community of which he forms part. He must accept his fair share of responsibility for the performance of social duties and also his share of any sacrifices made necessary by the exigencies of life in common.

[Section 1b was inserted from the bottom of the page and became Article III of the first typed draft]

2. In the exercise of his rights every one is limited by the rights of others and by the just requirements of the democratic State.

[Article IV of first typed draft]

3. Every one has the right to life.

[First section of Article $V$, first typed draft] torture.

[very faint aide-mémoire to insert text appearing on sheet 4]

4. Every one has the right to personal liberty. [Article VII of first typed draft]

\section{Sbeet 2}

\section{Preamble}

Man does not have rights only, he owes duties to the society (national and international) of which he forms part

1. It is solemnly declared that the principles here enunciated are matters of international concern. No plea of sovereignty shall ever again be allowed to permit any nation to deprive

[inserted from lower on the page]

\section{Rights and Duties within the State}

Right to Liberty and Freedom

Right to Social Security

Right to Equality and Protection against Discrimination

Limitations

Rights and Duties as Member of International Community

Right to live out his days secure from war and the fear thereof.

Incorporation of Declaration into National Law (See Inter-American)
Sheet 3

\section{Declaration of International Concern}

It is solemnly declared that the principles enunciated by this International Bill of Rights are matters of international concern and within the jurisdiction of the United Nations. No plea of sovereignty shall (ever again) be allowed to permit any state to deprive men and women within its borders of the rights established by it .

The provisions of this International Bill of Rights shall be deemed fundamental principles of International law and of the national law of each of the member states of the United Nations to be realized by appropriate action of international and national agencies. Respect for these principles is therefore a matter of international concern and it shall be within the jurisdiction of the U.N. to discuss any violation thereof.

It is the duty of the state to respect and maintain the rights enunciated in this Bill of Rights.

[Appears upside down at the bottom of the page]

Sheet 4 (Verso of sheet 3).

This right can be denied only when the person concerned has been convicted under general law of some crime against society to which the death penalty is attached.

[This is an addition to 3 on sheet 1, becoming the second sentence of Article $V$ of the first typed draft]

No one shall be subjected to torture or to any unusual punishment, torture or or indignity.

[Text for aide-mémoire on torture on sheet 1 and became Article VI of first typed draft]

[The remaining two paragraphs appear upside-down at the bottom of the sheet]

\section{The enjoyment of rights}

Every one, moreover, owes a duty of loyalty to the society whether both national or and international of which he forms part. He must accept his just share of responsibility for the performance of social duties and accept also his 
share of any common sacrifice made necessary by the exigencies of life in common.

[Variant text for Ib on sheet 1]

\section{Sheet 5}

There shall be full equality before the law in the enjoyment of the rights enunciated in this Bill of Rights and no one shall suffer any discrimination whatsoever because of race, sex, language or religion.

[Cf. Article XXXVII of first typed draft]

Having regard to UNESCO

UNESCO is, of course, interested in the freedom of information and has expressed a desire to cooperate with the U.N. be represented at the proposed int. conference on that subject. Under

The Council may therefore wish to request the G.A. to change the date of the

[These notes refer to the possible rescheduling of the International Conference on Freedom of Information (eventually held at Geneva in March - April 1948), given UNESCO's expressed interest. Having nothing to do with the draft they probably represent some work interruption and the utilization of a handy piece of paper $^{35}$ ]

\section{Sheet 6 (Verso of sheet 5)}

Every one has a right to own personal property. His right to share in the ownership of industrial, commercial and other profit-making enterprises is governed by the laws of the State of which he is a citizen.

[C.f. Article XXII, sheet 12]

Every one shall

[This probably represented the start of Article IX (see infra) since this is the only article in the first typed draft beginning with these three words]
[The remaining two paragraphs are written upside-down at the bottom]

and to live in healthy pleasant surroundings.

[this hanging phrase is written in ink and represents concluding phraseology, eventually not used, for Article XXXI]

Every one has the right to good food and to housing, and to live in surroundings that are pleasant and healthy.

[Article XXXI of first typed draft]

\section{Sheet 7}

Subject to the laws governing slander and libel there shall be full freedom of speech and of expression by any means whatsoever, and there shall be reasonable access to all channels of information communications. Censorship shall not be permitted, [one illegible word erased]

[Cf. Article XVIII, sheet 11]

There shall be free access to all sources of information both within and beyond the borders of the State.

[This erasure became Article XVII, Sheet 10]

The press is bound by a sacred duty towards society to present the news in a fair and impartial manner.

[Cf. Article XIX, Sheet I1]

\section{Sheet 8}

[At this point draft articles are given Roman numerals beginning with $\mathrm{X}$ ]

$X$. No one shall be convicted of crime except for violation of a law in effect at the time of the commission of the act charged as an offense [text corrected from "offence" to reflect this spelling], nor be subjected to a penalty greater than that applicable at the time of the commission of the offense. 
René Cassin and the Daughter of Time

XI No one thace be rubjectió to arbibriry Rearehes ov seezcirios of to nuicasomable cullifereiver cieile his Rerzen, family reerclonio.

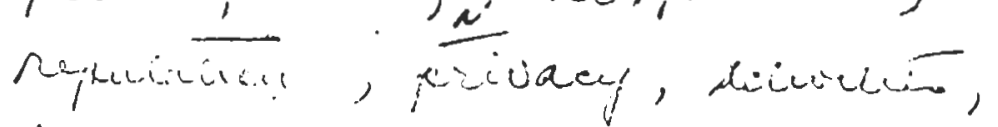

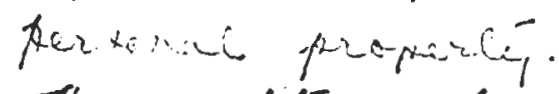

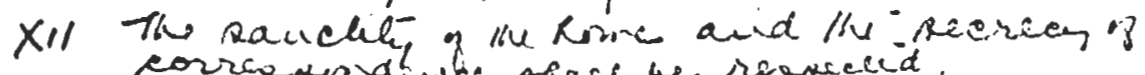

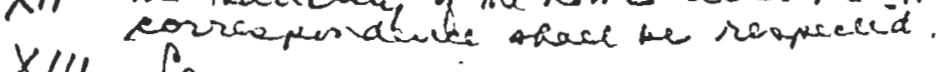

XIII Slavery and compuceory lakour

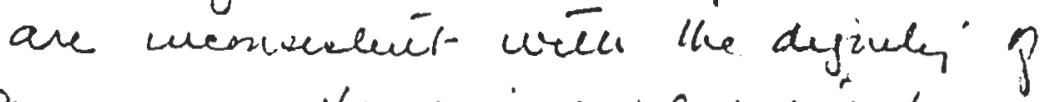

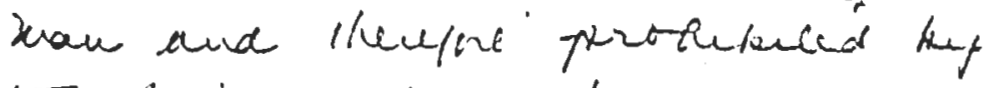
thes their g tegits. Thut a man may be requeret to pertorm thi guir thare of any phusbic rervece thaik is equacly mecumbent uprom all, and his rygh $x$ a livelurand io tonduhuici ing hid dich o work.

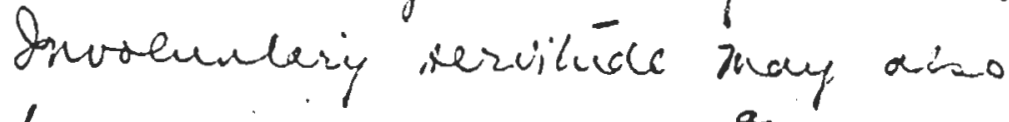
he unparai to pact of pucushanat-

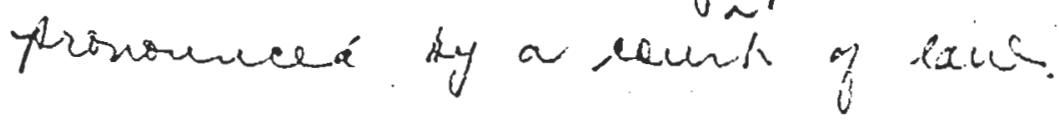

Figure 3. Sheet IX of the manuscript draft. Courtesy of McGill University Law Library.

17 
Sheet 9 (Figure 3)

XI. No one shall be subjected to arbitrary searches or seizures or to unreasonable interferences with his person, bome, correspondence family relations, [this phrase was substituted for the erasure], reputation, privacy, activities, and or personal property.

XII. The sanctity of the home and the secrecy of correspondence shall be respected.

[This clause appears to have been added afterwards, presumably when the concept was removed from Article $\mathrm{XI}$, causing renumbering up to at least Article XX]

XIII. Slavery and compulsory labour are inconsistent with the dignity of a man and therefore prohibited by this Bill of Rights. But a man may be required to perform his just share of any public service that is equally incumbent upon all, and his right to a livelihood is conditioned by his duty to work. Involuntary servitude may also be imposed as part of a punishment pronounced by a court of law.

Sheet 10

XIV. Subject to any general law adopted in the interest of national welfare or security, there shall be liberty of movement and free choice of residence within the borders of each State.

XV. The right of emigration and expatriation shall not be denied.

XVI. There shall be full freedom of conscience and belief and of religious worship. Every one ${ }^{36}$ has the right to form, to hold, and to receive opinions.

XVII. There shall be free access to all services of information both within and beyond the borders of the State.
Sheet 11

XVIII. Subject only to the laws governing slander and libel, there shall be full freedom of speech and of expression by any means whatsoever, and there shall be reasonable access to all channels of communication. Censorship shall not be permitted.

XIX. The press is bound by a sacred duty towards society to present the news in a fair and impartial manner.

Sbeet 12

XX. There shall be full freedom of peaceful assembly.

XXI. There shall be full freedom to form association for purposes not inconsistent with this Bill of Rights.

XXII. Every one has a right to own personal property. His right to share in the ownership of industrial, commercial and other profit-making enterprises is governed by the law of the State of which he is a citizen.

Sheet 13

XXIII. Every one is entitled to the nationality of the State where he is born unless and until on attaining majority he declares for the nationality open to him by virtue of descent.

No one shall be deprived of his nationality by way of punishment or be deemed to have lost his nationality in any other way unless he concurrently acquires a new nationality.

Every one has the right to renounce the nationality of his birth, or previously acquired nationality, upon acquiring the nationality of another State. 


\section{René Cassin and the Daughter of Time}

Sheet 14

XXIV. No alien who has been legally admitted to the territory of a State may be expelled except in pursuance of a judicial decision or recommendation as a punishment for offences [British variant used here but transcribed "offenses" in first typed draft] laid down by law as warranting expulsion.

XXV. Every one has the right to take an effective [adjective added later] part in the government of the State of which he is a citizen. The State has a duty to conform to the wishes of the people as manifested by democratic elections.

XXVI. Every one has the right, either individually or in association with others, to petition the government of his State or the United Nations for redress of grievances.

Sheet 15

XXVII. Every one has the right to education. Each State has the duty to require that every child within its territory receive a primary [adjective added later] education. Within the limits of its economic capacity and development, the State must maintain

The State shall maintain, within the limits of its economic capacity and development, adequate and free facilities for such education. It shall also promote facilities for higher education

XXVIII. Every one has the right and the duty to perform socially useful work.

XXIX. Every one has the right to good working conditions.

Sheet 16

XXX. Every one is entitled to adequate food and housing.
XXXI. Every one bas the [change from "a'"] right to social security. To this end the State must promote measures [measures was erased earlier than the remainder of the paragraph.] public bealth and safety. This right includes the right to bealth in so far as

XXXI. Every one has the right to leisure. [Cf. Article XXXI, Sheet 18]

XXXII. Every one has the right to culture and to the enjoyment of the arts.

[Cf. Article XXXII, Sheet 18]

XXXIII. Every one has the right to share in the benefits of science.

[Cf. Article XXXIII, Sheet I8]

XXXIV. Every one has the right

The State shall promote public health and safety.

XXXIV. Every one has the right to social security. To this end each State shall within the limits of its economic capacity and development promote public bealth and safety, and establish

Sheet 17 (verso of Sheet 16)

XXXIV. Every one has the right to live and work in healthy surroundings and a right to medical care.

XXXV. Every one has the right to social security. To this end, each State shall, within the limits of its economic capacity and development, promote public health and safety. and establish systems of social insurance and social agencies It shall also make effective provisions for public maintain or ensure that there are maintained effective arrangements for the prevention of unemployment, for the provision of adequate insurance compensation in the event of against the risks of unemployment, accident, disability, ill health, sickness, old age or other involuntary loss of livelihood. including 
Sheet 18

XXX. Every one has the right to a fair share reasonable reasonable just wage and standard of living.

[This is the last entry in pencil, the remainder of the manuscript being in ink]

XXX. Every one is entitled to adequate food and housing.

XXXI. Every one has the right to a fair share of rest and leisure.

[Article XXXII of first typed draft]

XXXII. Every one has the right to participate in the cultural life of the community and to enjoy the arts.

[Article XXXIII of first typed draft]

XXXIII. Every one has the right to share in the benefits of science.

[Article XXXIV of first typed draft]

XXXIV. Every one bas the right to social security. To this end each State shall, within the limits of its economic capacity and when necessary in cooperation with other States,

The remainder of the handwritten sheets are a table of contents or arrangement for subsequent drafts. The first typed draft, annotated but undated, contained 37 articles. The second typed draft of February 27, 1947, also contained 37 articles. It was not until the third typed draft, annotated as "shown to Mrs. Roosevelt Feb 28, 1947" (Figure 4), that the document expanded to 50 articles and followed the arrangement noted above. It is clear, therefore, that these remaining five sheets were prepared for the third typed draft or an even later document and did not form part of the original draft. ${ }^{37}$

\section{The First Typed Draft}

The first typed draft indicates what parts of the manuscript were used, what were discarded and what are probably missing. Only those parts which are new or indicate the text Humphrey ultimately preferred, for example how he solved the obviously thorny problem of the right to social security, are given below. Also included are the annotations Humphrey made on the draft.

The introductory matters are quite different from the manuscript and read as follows:

The Preamble shall refer to the four freedoms and to the provisions of the Charter relating to human rights and shall enunciate the following principles:

1. that there can be no peace unless human rights and freedoms are respected;

2. that man does not have rights only; he owes duties to the society of which he forms part;

3. that man is a citizen both of his State and of the world.

Article $I$ is as it appears on sheet 1 - Humphrey changed the first word of the second sentence "Its observance" becoming "Their observance". He added the marginal annotation "Bring in as last paragraph".

Article II, la on Sheet 1, has the marginal annotation "Bring in as penultimate paragraph." Humphrey also added a second sentence as follows:

The State shall, when necessary, cooperate with other States to this end.

Articles III to VII appear as noted on the manuscript sheets.

Article VIII does not form part of the extant manuscript. The text reads:

No one shall be deprived of his personal liberty save by a judgement of a regular court of law, in conformity with the law and after a fair public trial at which he has had an opportunity for a full hearing, or pending trial in accordance with the law and within a reasonable time after his arrest. Detention by purely executive order shall be unlawful except in time of national emergency. 


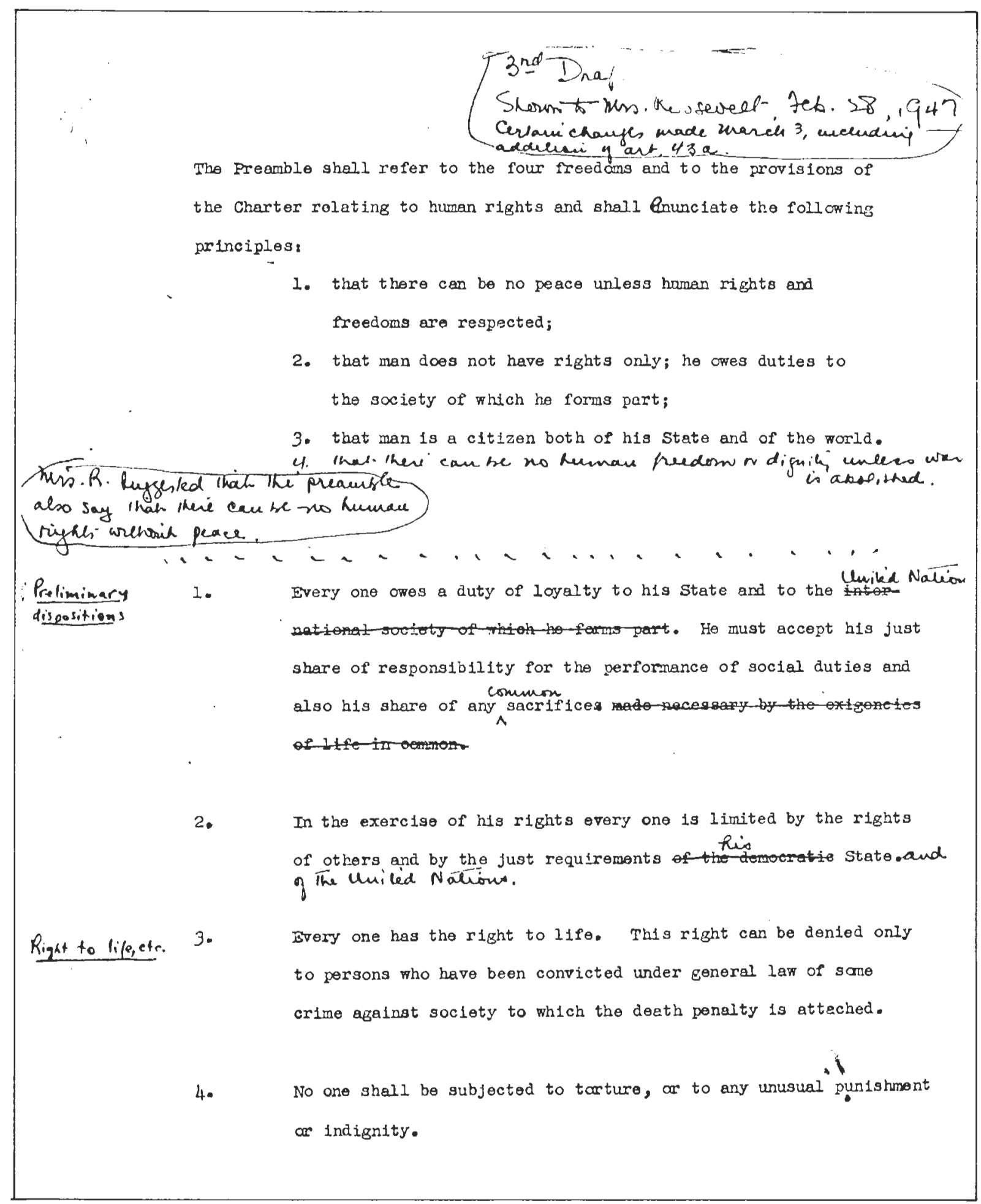

Figure 4. First page of the third typed draft. Courtesy of McGill University Law Library. 
Humphrey altered the conclusion of the first sentence to read "...full hearing, or pending his trial which must take place within a reasonable time after his arrest."

Article IX which is also not found in the manuscript, reads:

Every one shall be protected against arbitrary and unauthorized arrest. He shall have the right to immediatc judicial determination of the legality of any detention to which he may be subject.

Articles X to XXIX were typed exactly as they appear in the manuscript. Humphrey added one "therefrom" to Article XXIV the relevant part of which then read "... territory of a state may be expelled therefrom except in pursuance..."

Article XXX differs substantially from the manuscript and reads:

Every one has the right to such equitable share of the national income and wealth as the need for his work and the increment it makes to the common welfare may justify.

Article XXXI appears on sheet 6 and Articles XXXII to XXXIV on sheet 18 .

The concept of Article XXXV was originally part of Article XXXIV (see sheet 17) but now stands on its own as:

Every one has the right to medical care.

Article XXXVI dealt with social security. This was the concept which interrupted the free flow of ideas in the manuscript draft, which from Article X to XXIX had been remarkably coherent and polished. The final text reads:

Every one has the right to social security. The State shall promote public health and safety and shall maintain effective arrangements for the prevention of unemployment and for insurance against the risks of unemployment, accident, disability, sickness, old age and other involuntary or undeserved loss of livelihood.
Article XXXVII embraces the concept of nondiscrimination noted on sheet 5 . The final text reads:

There shall be full equality before the law in the employment of the rights enunciated in this Bill of Rights. In particular, no one shall suffer any discrimination whatsoever because of race, sex, language, religion, or political creed.

\section{Conclusion}

It appears clear that the first draft of what became the Universal Declaration of Human Rights was written not by Cassin in June 1947. but by Humphrey in the preceding February. The Humphrey draft was solicited by the Drafting Group of the Commission on Human Rights for the express purpose of being the departure point for drafting the International Bill of Human Rights. It was also used by Cassin when he wrote his subsequent draft. These conclusions seem inescapable based on the documentation and the historic record. The only sense in which Cassin can be said to be the author of the first draft would be if his draft were quite original, not derivative, and formed the exclusive basis of discussion for the subsequent activities of the Drafting Committee. However, this is doubtful and, indeed, the U.N.'s published history of the events made it clear that the Secretariat Outline came first and was equally prominent with several other drafts in the discussions. ${ }^{38}$

The most significant support for the Humphrey claim comes, oddly enough, from Cassin himself. In one of his earlier articles, a carcfully documented study written soon after the events, his description closely parallels the Humphrey version and the official U.N. record. He was accurate on such things as the facts that the Drafting Committee first met on June 9, that the Rapporteur was Charles Malik, that Giraud's role was secondary to Humphrey's, and that his own role was to "présenter, seul,... un projet ordonné de déclaration tenant compte des travaux du secretariat..." He noted that Roosevelt had established the Fcbruary Drafting Group to "élaborer, avec le concours du secrétariat, un premier avant-projet de 


\section{René Cassin and the Daughter of Time}

déclaration..." Of his own draft, which he consistently termed a "projet" not an "avantprojet", Cassin noted that it did contain some new material. Specifically he stated "Ce projet précédé d'un Préambule et d'une partie générale entièrement neufs..."39 All of this appears generally consistent with the events and contrary to his later recollections.

René Cassin did not get the Nobel Peace Prize for writing the first draft of the Universal Declaration. He received it deservedly for a lifetime of dedication and effort to the cause of human rights, including his share in the drafting of the Declaration. It is not clear why he claimed to have authored the first draft although several possibilities suggest themselves. ${ }^{40}$ Nor is it clear why the claim, so evidently at variance with the record, has been so readily accepted. Malik was clearly disturbed by some of the "facts" quoted in the plethora of articles which came out in 1967 and 1968. In this regard he wrote:

The complete story of how each provision actually arose can never be told, because the actual, living, dynamic process of genesis can never be recaptured or reproduced. And the claims made and published about some provisions are not altogether true, as can be shown by a more thorough research into the available documents, and especially by reference to some unpublished diaries. It seems that the Declaration has already generated, especially in the Human Rights Year of 1968 , a great deal of interest, and therefore the authoritative writing up of its total story could claim the attention of some of us who knew more about the truth of the matter than others. ${ }^{41}$

Malik does not appear to have written much on the drafting process beyond these few tantalizing remarks. One wonders to which published claims and unpublished diaries he is referring.

Yet the facts appear clear. Truth, we are told by Aulus Gellius ${ }^{42}$ citing some other poet whose name he had forgotten, is the Daughter of Time. Cassin died full of honours after a lifetime of public service, and nothing should detract from this. Yet Time will almost certainly show that John Humphrey deserves the credit for composing the first draft. However, Humphrey feels that such credit is inappropriate and that the universality of the Declaration transcends the need for recognition of the contributions of individuals. He articulated this view as follows:

The Universal Declaration of Human Rights has no father in the sense that Jefferson was the father of the American Declaration of Independence. Very many people - in the Commission on Human Rights, in its drafting Committee, in the Commission on the Status of Women, in the two subcommissions, in the specialized agencies, in departments of national governments and in the non-governmental organizations contributed to the final result. It is indeed this very anonymity which gives the Declaration some of its great prestige and authority. ${ }^{43}$

Perhaps it is just that Humphrey should have the last word on the issue. 


\section{Notes}

1. New York Times, 10 October 1968, p. 1, quoting from Nobel telegram.

2. René Cassin, "How the Charter on Human Rights was born," UNESCO Courier, $\mathrm{x} \times \mathrm{I}$ (January, 1968), p. 4, and his "Quelques souvenirs sur la Déclaration universelle de 1948," Revue de droit contemporain, XV.1 (1968), p. 6.

3. Cassin, "How the Charter...," p. 4.

4. Cassin, "Quelques souvenirs...," p. 5.

5. Cassin, "Quelques souvenirs...," p. 6

6. Humphrey (1905- ) is a graduate of McGill University and has been on its law Faculty since 1936. From 1946-66 he was Director of the Division of Human Rights, U.N. Secretariat. His dissenting view on the first draft has become increasingly explicit in his various publications over the years, and is most fully explained in his monograph Human Rights $\&$ the United Nations: a Great Adventure (Dobbs Ferry, N. Y., Transnational Publishers, 1984).

7. United Nations Commission on Human Rights, "Report," Economic and Social Council Official Records, 2nd Year, 4 th Session, Supplement 3 (E/259), p. 2.

8. United Nations Commission on Human Rights, Summary Record of the Twelfth Meeting (Document E/CN.4/SR.12, February 3, 1947), p. 5 .

9. René Cassin, "La Déclaration universelle et la mise en oeuvre des droits de l'Homme," Receuil des Cours, LXXIX. 2 (1951), p. 273.

10. United Nations Commission on Human Rights, Summary Record of the Eleventh Meeting (Document E/CN.4/SR 11, Fel)ruary 3, 1947), p. 4.

11. Document $\mathrm{E} / \mathrm{CN} .4 / \mathrm{SR} 12$ cited at note 8 , pp. 2-4.

12. United Nations General Assembly Third Session, Verbatim Record of the One Hundredth and Eightieth Meeting (Document A/PV.180, Dececember 9, 1948), p. 48.

13. Eleanor Roosevelt, On My Oun (New York, Harper, 1958), p. 77. John P. Humphrey, "The Universal Declaration of IIuman Rights: Its History, Impact and Juridical Character,"
Human Rights: Thirty Years after the Universal Declaration, ed. B. G. Ramcharan (The Hague, Nijhoff, 1979), p. 23.

14. Document A/PV. 180, cited at note 12, p. 47.

15. The text of Roosevelt's letter to the President of the Economic and Social Council (ECOSOC) appears in Commission on Human Rights, Drafting Committee, Memorandum and Historical Background of the Committee (E/CN.4/AC/1/2), p. 5-6. Humphrey felt the action might be illegal since only the Commission could change the composition of the Committee. Humphrey, "Universal Declaration...," p. 23.

16. Cassin, "Quelques Souvenirs...," p. 3. It is difficult to see how the latter criticism could apply to the first committee since Cassin wrote no texts for it. Perhaps this should be taken as a generalized critique of the whole early period or the way the Summary Records reported his verbal remarks.

17. The President of ECOSOC"s reply is in Document $\mathrm{E} / 325, \mathrm{p} .2-3$. His acceptance of Roosevelt's changed committec cleared up any questions of legality mentioned in note 15 since the Council was the Commission's superior body.

18. The actual documents, all of which contained the word "outline" in their title, submitted by Humphrey to the Drafting Committee were the following:

1. Draft Outline of International Bill of Rights/Avant-projet de la déclaration internationale des droits de l'bomme (Document E/CN.4/1/3, June 4, 1947).

The text of Humphrey's draft with official French translation and known as the Secretariat Outline.

2. Documented Outline (Document E/CN.4/AC/1/3/Add.1, June 2, 1947).

408 pages of supporting documentation which contained observations by members of the Commission, draft declarations from Chile, Cuba and Panama, proposals from India and the U.S.A., and excerpts from many national constitutions and other documents on human rights. These arranged as a commentary on the Secretariat Outline, article by article. 


\section{René Cassin and the Daughter of Time}

3. Plan of the Draft Outline of an International Bill of Rights (Document E/CN.4/AC/1/3/Add.2, June 9, 1947).

The conceptual arrangement of the Secretariat Outline the only true "outline" submitted.

4. Document Outline (Document E/CN.4/AC.1/3/Add.3, June 10, 1947).

A textual comparison between the Secretariat Outline and a draft International Bill of Human Rights submitted by the United Kingdom, which was intended to be a convention.

19. Document A/PV 180 cited at note 12, p. 46.

20. United Nations Commission on Human Rights, Drafting Commitce, First Session. Report of the Drafting Committee to the Commission on Human Rights (Document E/CN.4/2 1 July 1, $1947)$, p. 4 . There is some irony in the fact that the Secretariat Outline was drawn up by a single individual. It was simply an error on Cassin's part to state the request was made towards the "fin de mai". "Quelques souvenirs...," p. 5.

21. Giraud was one of Humphrey's assistants in the Division. Cassin does not mention his assistance, the only references to it being found in Humphrey's writings, e.g. Human Rights..., p. 42 .

22. Cassin, "Quelques Souvenirs...," p. 6 and "How the Charter...," p. 4.

23. Marc Agi, René Cassin: Fantassin des droits de l'bomme (Paris, Plon 1979), p. 221.

24. Humphrey, "Universal Declaration...," pp. 24-25. He goes into greater detail on the comparison in his Human Rights..., pp. 44-45.

25. Humphrey, Human Rights..., p. 31.

26. Document A/PV 180 cited at note 12 , p. 46.

27. René Cassin, "Twenty Years after the Universal Declaration," Journal of the International Commission of Jurists, IX. 1 (1968), p. 1.

28. Agi, René Cassin p. 220 writes:

Devant l'amas considérable de matériaux, il [Le Comité de redaction] désigne pour gagner du temps un rapporteur unicue en l'occurence René Cassin - et le chárge de procéder au premier grand travel de dépouillement.
President Giscard d'Estaing also styled Cassin as Rapporteur in a letter to the President of L'Association pour la fidélité à la pensée de René Cassin, published in Actualité de la pensée de René Cassin (Paris, CNRS, 1981), p. 11.

29. Humphrey, Human Rights..., p. 43.

30. René Cassin, La pensée et l'action (Paris, 1.alou, 1972).

31. These form a fraction of the Humphrey Human Rights Collection, which consists of the publications of the Commission on Human Rights, its sub-bodies, and the Economic and Social Council. Humphrey donated this major collection soon after his retirement from the Secretariat in 1966 and it has been kept up-todate. The manuscripts were separated from the main collection and placed in acid-free envelopes by Michael Renshawe, Law Area Librarian from 1976-88.

32. Humphrey acknowledges borrowing freely from these documents, in particular that of the American Law Institute. They are fully listed in his Human Rights..., pp. 31-32.

33. Humphrey, in reviewing a draft of this article could not confirm the dates nor did he have any recollection of showing a draft to Mrs. Roosevelt. Indeed he believed, as stated in his published work, that the drafting was done in late April or May in response to the request for an outline. He now accepts, since the dating on the mimeograph is conclusive, that the work was done prior to the expansion of the Drafting Committee on March 24 and in response to a request for a draft declaration. There was a marginal annotation on the third typed draft of a change suggested by Roosevelt which was incorporated into the fourth typed draft. It is likely, therefore, the dates were written at the time, or added very soon afterwards. See Figure 4 .

34. It seems probable that the 6" $\mathrm{x} 9$ " sheets represented the draft given to the typist and that the first four or five of these are missing. These would cover the Preamble and Articles I to $1 \mathrm{X}$. However, this is no more than speculation.

35. Humphrey found that writing a draft in his office was practically impossible owing to interruptions. Eventually he was given a week's leave of absence to complete the task. Human Rights..., p. 31 . 
36. Humphrey intended that "every one" be spelled as two words, and his preference is reflected in this reproduction of the manuscript. However, on occasion the space between the two handwritten words is sufficiently imperceptible as to be read "everyone". In the first typed draft "everyone" is consistently used prior to this point and "every one" from here to the end. The two word variant appears in all subsequent drafts.

37. It is also possible, though less likely, that these sheers were written as late as June, being the draft for Document E/CN.4/AC/ 1/3Add.2 cited at note 14 .

38. These Rights and Freedoms (New York, United Nations, 1950), p. Gff.

39. Cassin, "La Déclaration universelle...," pp. 273-4.

40. It should be remembered that Cassin's assertions were were written mostly in the late 1960's when he was over eighty. His memory was evidently faulty on details. Doubtless his friends and colleagues also pressed his case as much as he did.

41. From his introduction to the pamphlet by Otto F. Nolde, Free Equal: Human Rights in Ecumenical Perspective (Geneva, World Council of Churches, 1968), p. 12. Malik never took up his own challenge to create an authoritative history. The U.N. attempted to write a legislative history for the twentieth anniversary of the Declaration, but the project was abandoned after three years. ECOSOC, Council Resolutions, 940 (XXXV) April 15, 1963. Annex 1. 3e. and 1160 (XLI) August 5, 1966.

42. Noctes Atticae. Book XII, Chapter 11 , "Alius quidem veterum poetarum, cuius nomen mihi nunc memoriae non est, Veritatem Temporis filiam esse dixit."

43. Humphrey, Human Rights..., p. 43.

44. Two pictures of Humphrey and Roosevelt, firstly at work on the Declaration and secondly sharing a joke in a more convivial setting. Reproduced courtesy of John Humphrey.

45. This publicity poster shows the Declaration in three languages with some of the principal architects superimposed. Seated in the foreground from left to right, are P.C. Chang, Henri Laugier (Assistant Secretary-Cieneral and Humphrey's immediate Superior), Eleanor
Roosevelt, John Humphrey, Charles Malik and V.M. Koretsky of the U.S.S.R. In the background are some of Roosevelt's advisors from the State Department, including James Hendrick to Humphrey's immediate left. Cassin is not shown in this poster. Reproduced courtesy of John Humphrey.

\section{Acknowledgement}

The author wishes to express his gratitude to colleagues in McGill University Libraries and Faculty of Law for their help in preparing this article. 